\title{
Social Media Influencer in Wayang Performance: the Punakawan
}

\author{
A N Hidayati $^{1}, \mathrm{R}$ W Winarni ${ }^{2}$, D Pratama $^{3}$, A Nurfarkhana $^{4}$ \\ Faculty of Language and Art, Universitas Indraprasta PGRI Jakarta Selatan, Indonesia ${ }^{1,2,3,4}$ \\ \{atiek.nurhidhayati@unindra.ac.id $\left.{ }^{1}\right\}$
}

\begin{abstract}
Nowadays, the role of social media influencer in introducing a brand and raising brand awareness through social media is quite significant. Even though most of the social media influencers are not celebrities who have previously been famous in conventional media, they hold the same significant role in influencing the society. In the world of Wayang, there exist characters who have roles akin to the social media influencers that introduce messages from sponsors or brands within the Wayang performances. These characters are called the Punakawan, four Wayang characters that have a more fluid and comedic dialogue in Wayang performances. The audience of Wayang performances always eager to see the Punakawan to appear on the performance even though they are not the central figure of the story. With the increasing use of social media and the important role of social media influencer in this digital era, it is imperative to understand how these Punakawan characters carried themselves out in Wayang performances to better understand the way personal branding can be used to enhance the role of social media influencers. This article will analyze the characters of four Punakawan by using personal branding strategy approach based on eight main concepts of personal branding to understand the image of the Punakawan and the way they represent themselves within the society. The result is that the social media influencer and the Punakawan Characters have a similar role that is to deliver messages through the way that already becomes almost every person's favorite. The difference is a social media influencer could have just deliver any positive and negative impact to the audience. However, the Punakawan would always deliver a positive impact due to their presence is already being a part of the cultural heritage that always brings values of humanity and kind-heartedness
\end{abstract}

Keywords: Personal Branding, Punakawan, Social Media Influencer.

\section{Introduction}

Social media is being used as an alternative media in the field of marketing and advertising. The presence of social media influencers was mentioned as the next-generation of brand ambassadors that can help a brand to become more famous and increase consumption in society through social media. Social media influencers represent a new type of person who influences audience attitudes through blogs, tweets, and other social media[1]. Social media influencer can be a celebrity or just a common person next door with a high number of 
followers. What makes them a social media influencer depend on their positioning in the world of social media. Their positioning is formed using personal branding inherent to the online persona created by each of them. Personal branding can be defined as the formation of a brand on a person, so that the ability, personality, and unique characteristic possessed are different and can be easily distinguished from others. Successful personal branding entails managing perceptions effectively and controlling and influencing how others perceive you and think of you [2]. Personal branding is all about controlling how people see others before they connect and directly get in touch with each other [3].

In the world of Wayang, there exist characters called Punakawan who have roles akin to the social media influencers. Their comedic presence is always eagerly awaited by the audience because they can always break the ice amidst conflicts that occur in the Mahabharata story. Punakawan is described as the closest people to the Pandawa knight and appeared as commoners or people who did not hold any position. Punakawan is not the central figure in the Wayang world, but that does not mean they do not hold any influence. The message they conveyed is often easier for the audience to accept because they used everyday language close to the audience to communicate the message. The personal branding strategy of the Punakawan is reflected in the stories, messages conveyed, and the characters of each Punakawan figure who was present at the Wayang performances. The Punakawan consists of four figures, namely Semar, Gareng, Petruk, and Bagong. Each of the characters has its origins and personality which reflects the philosophical life of Javanese society.

With the increasing use of social media and the important role of social media influencer in this digital era, it is imperative to understand how these Punakawan characters carried themselves out in Wayang performances to better understand the way personal branding can be used to enhance the role of social media influencers. This article will discuss how thePunakawan establish their characters by using personal branding strategy approach based on the eight main concepts of personal branding. The analysis also observes the similarities and differences in the roles of Punakawan and social media influencers in influencing their audiences.

\section{Method}

The approach which is used in this article is a qualitative approach with a constructive perspective. The research subject is the characters of Punakawan which assumed as the noncelebrities social media influencer roles in the Wayang performance. The Punakawan Characters could become an influencer to the Wayang audience is caused by the way they deliver any messages are full of comedy, and it is also well-accepted by all audiences. Furthermore, the analysis units are to connecting the eight law of personal branding with the character of Punakawan in delivering messages in Wayang performance. Those eight law of personal branding is specialization, leadership, personality, distinctiveness, visibility, unity, persistence and goodwill.

\section{Result and discussion}

\subsection{Punakawan Figure in Wayang Performance}

Wayang as art has already known before The Hindu culture broadened in Indonesia, and the stories in wayang have firmly attached to Javanese culture [4]. Punakawan is the 
characters only exist in Indonesian Wayang puppet stories, which has the basic purposes of spreading Islam. Afterward, Punakawan becomes media, information media, and socialcriticizing media for inadequate people. Basically, Punakawan is the representation of human characters and form which has their values that could be as a role model for humanity. They characters in Punakawan are always devotedly come along with the Pandawa. In the Wayang performance, they always appear in the scene of Goro-Goro as an entertainer, deliver messages, freely at liberty from any conventions, and also build a dialog with the audience. The information deliverd could be about the updated and the latest-actual issues in the current period of time.

The Characters in Punakawan consist of a father with his three-step boys; those are Semar, Gareng, Petruk, and Bagong. Semar is a caretaker for Pandawa, and has tremendous powerful strength higher than the gods. $\mathrm{He}$ is a humble, calm, low-profile, generous, genius, knowledgeable and proficient. Gareng as the eldest son which has many imperfections in his physical appearance that symbolize human characters. He speaks shabbily, almost always misspelling. Petruk, the second son, has a smiling face. He is a generous person, speaks elegantly smart, sometimes delivers social critic through comedy. Petruk has a highly straight body, long arms and legs, which means in life one must think everything over in order avoid disappointments. The last one, is Bagong, also said as the shadow of Semar. He speaks untidily, reckless, almost always foolish. But then he is also reliable, trustworthy, and the Pandawa knights admire him instead.

\subsection{Punakawan Personal Branding Analysis}

The wayang's audience has already had a perception about the Punakawan characters as an entertainer, and always deliver the brand's message. These influential Punakawan characters, whether individually or collectively, often occupied as mascot or visual image of a particular product. Punakawan as a brand has its own impactful personal branding which formed by the creators in the previous era. They are created in Wayang stories with the aim of delivering philosophic values which can be easily taken by society.

Essentially personal branding shape one's perception to other individuals, therefore without direct interaction, a person may get a big picture of the particular individual. Building personal branding is a continuous process, that they must recognize the perception they build in other people's mind [5]. The process involves three phases, the first step is to build brand identity, the second is to develop brand positioning, and the third is to evaluate the brand image [6].

Personal Branding is rather more important then corporate branding since people tend to believe to a person, as well as a person seems more responsible than a corporate. Personal branding is a form of trust so people might get influenced easily to any words said by the person who owned a good personal branding. Personal branding of a person must be authentic, honest, fit to the purpose of life, moral values, uniqueness, specialization, self-characterized. If other people's perception of the person matches with their brands, consequently other people would interested, believe, and simply manipulated [7]. Those personal brand can be shaped. Therefore a person can decide how would he be like in other people's minds. There are eight main concepts that can be used as a benchmark in shaping personal brand [8], such as:

\subsubsection{The Law of Specialization.}

The role of Punakawan in the Wayang performance is as a counselor, as well as an entertainer, a social critics maker, even also as an honorable source of truth and spiritual 
advisor. Punakawan also means as assistance. In a Wayang Performance, Punakawan usually appears as a leisure-comedy session in the middle of a story; the main purpose is to provide the audience a time-break to avoid bored.

\subsubsection{The Law of Leadership}

Punakawan characters are created based on the original condition of various characters of Javanese people, the character indicates many roles, such as the counselor for the knights, entertainer, social critic maker, clowns, even also as an honourable source of truth and spiritual advisor. Punakawan is a half-Gods human who transformed into several unique characters, an ordinary people who own an excessive knowledge. That is why they would look normal when they convey advises.

\subsubsection{The Law of Personality [1]}

Semar is the center of the whole Punakawan itself. Semar often convey advises to Pandawa family. Many of the knights including the enemies also pay their highest respect to Semar. He is a modest, humble, honest figure and become the sample of a noble and wise character [2]. Gareng is Semar's step boy who has a different appearance, speaks shabbily, often misspelling. Gareng is one of the Punakawan character who has imperfect of anatomic body shape. He has abnormal legs, asymmetrical length of arms and crossed eyes [3] Petruk is the other son of Semar, who is diligent but a bit naughty. The shape of Petruk's body is slim and thin, with long legs and arms which symbolize deep and long consideration. As we also have to do the same thing, we must be careful in making decisions to meet expectations and to avoid not disappointments. Petruk is a communicative person and very funny, he likes to criticize social conditions in funny ways [4]. Bagong is the youngest child of Semar, who is created from the shadow of Semar. Bagong has the same character as his brothers; he also likes to be funny and acts foolishly.

\subsubsection{The Law of Distinctiveness.}

Punakawan is not an original character from MahabarataWayang performance, so they do not have a pure standard like another character in wayang performance. The presence of Punakawan, there was an opportunity to funny performance scenes so the audience would not feel bored. Because it does not exist in the original version, the Punakawan can spontaneously improvise in conveying the story.

\subsubsection{The Law of Visibility}

In Wayang performance, Punakawan has always appeared and become the audience's favorite act of scene. In the rules of Wayang performance, usually, the scene of the Punakawan is called Goro-Goro.

\subsubsection{The Law of Unity}

The character of the Punakawan is included in a story in wayang performance. The role of the Punakawan in Wayang performance is to be an advisor to Pandawa knight, entertainers, social critics and even a source of truth and virtue. Punakawan usually appears for comedy sessions in the middle of the story to give a short break, so the audience is not bored. 


\subsubsection{The Law of Persistence}

The Punakawan character from the start consistently conveyed life advise, brands and messages using comedy. In wayang performance, Punakawan is always accompanied by traditional songs. They use everyday language and humorous dialogue so that the audience understands the content of the story and can pick up hidden messages in Wayang performance.

\subsubsection{The Law of Goodwill}

The punakawan inspires the audience through dialogue that contains moral values that can be used as guide in living life. Moral values are contained in the implicit or explicit conversations between figures of Punakawan and other Wayang figures.

\subsection{Punakawanas Influencers}

The existence of Punakawan as an influencer in Wayang performance by the current existence of social media influencer, especially non celebrities social media influencer. They have similar character, as ordinary people, or they may not be a public figure; however they have enormous influence on the audience. Social media influencer works by endorsing products as a result of a positive impact on the audiences. Furthermore, the Punakawan are also endorsed and mention positive reflection to a particular product using entertaining humorous approach.

The products promoted by the social media influencer may vary; it depends on their characteristic and personal brand. They creatively express and explore how the brand message is delivered, not only to increase the quantity of audience but also to influence people's mind. Mean a while, besides in Wayang performance; whether they come up incomplete formation or as an individual figure, the Punakawan are often being used as these activities: a brand visualization to various kinds of products, social campaign endorser, and also as talents in commercial ads. The Punakawan characters have already hold a powerful personal brand attached to themselves, so when consumers who respond to the ads or brand of the products using the visual character or even their names, they would directly relate the brands as similar as the Punakawan characters in their perception of minds.

\section{Conclusion}

Punakawan as an original Indonesian cultural heritage is remarkable figures and in every period can always be tractable. The virtuous of communication abilities and their brand turns Punakawan as a social media influencer in the world of Wayang. The powerful personal brand reflects from the fulfilled of the eight main concepts of a personal brand has already reached by the Punakawan characters. Punakawan is suitable for delivering messages and entertaining criticizer to the audience due to the humble advises in every appearance. However, Punakawan and the social media influencer have creative strategies to deliver a message to please and entertain the audiences.

The differences between the Punakawan and the social media influencer are the impact they share to the audience. Nevertheless, Punakawan came from the powerful Javanese mythological figures which have numerous philosophic meanings, so they would always give good impact to the audience. On the other hand, social media influencer has the freedom to deliver any content of message through social media, which has more liberate boundaries so the impact may inadequate to the audience. 


\section{References}

[1] K. Freberg, K. Graham, K. McGaughey, and L. A. Freberg, "Who are the social media influencers? A study of public perceptions of personality," Public Relat. Rev., vol. 37, no. 1, pp. 90-92, Mar. 2011.

[2] H. K. Rampersad, "A new blueprint for powerful and authentic personal branding," Perform. Improv., vol. 47, no. 6, pp. 34-37, Jul. 2008.

[3] P. Montoya, The brand called you. New York, NY: McGraw-Hill, 2009.

[4] B. B. Tanudjaja, "Punakawan Sebagai Media Komunikasi Visual," Nirmana, vol. 6, no. 1, p. $16,2005$.

[5] K. M. Johnson, "The Importance of Personal Branding in Social Media: Educating Students to Create and Manage their Personal Brand," Int. J. Educ. Soc. Sci, vol. 4, no. 1, p. 7, 2017.

[6] M. Khedher, "Personal branding phenomenon," Int. J. information, Bus. Manag., vol. 6, no. 2, p. 29, 2014.

[7] S. Khamis, L. Ang, and R. Welling, "Self-branding, 'micro-celebrity'and the rise of Social Media Influencers,” Celebr. Stud., vol. 8, no. 2, pp. 191-208, 2017.

[8] P. Montoya and T. Vandehey, The personal branding phenomenon: realize greater influence, explosive income growth and rapid career advancement by applying the branding techniques of Michael, Martha \& Oprah. Peter Montoya, 2002. 